\begin{tabular}{|c|c|c|}
\hline \multirow{3}{*}{$\begin{array}{r}\text { Case Reports in } \\
\text { Gastroenterology }\end{array}$} & \multirow{2}{*}{\multicolumn{2}{|c|}{ Case Rep Gastroenterol 2014;8:134-140 }} \\
\hline & & \\
\hline & $\begin{array}{l}\text { DOI: 10.1159/000362537 } \\
\text { Published onlıne: April 10, } 2014\end{array}$ & $\begin{array}{l}\text { ○ } 2014 \text { S. Karger AG, Basel } \\
\text { 1662-0631/14/0081-0134\$39.50/0 } \\
\text { www.karger.com/crg }\end{array}$ \\
\hline & \multicolumn{2}{|c|}{$\begin{array}{l}\text { This is an Open Access article licensed under the terms of the Creative Commons } \\
\text { Attribution-NonCommercial } 3.0 \text { Unported license (CC BY-NC) (www.karger.com/OA } \\
\text { license), applicable to the online version of the article only. Distribution permitted for non } \\
\text { commercial purposes only. }\end{array}$} \\
\hline
\end{tabular}

\title{
A Case of Successful Remission of Extensive Primary Gastric Diffuse Large B Cell Lymphoma: Radiologic, Endoscopic and Pathologic Evidence
}

\author{
Mike M. Bismar ${ }^{\mathrm{a}} \quad$ Mazen Alasadi ${ }^{\mathrm{a}}$ Bassem S. Hendawy ${ }^{\mathrm{c}}$ \\ Abdelkarim Waness ${ }^{b}$ \\ Departments of ${ }^{a}$ Gastroenterology and Hepatology and ${ }^{b}$ Medicine, Mafraq Hospital, \\ and ${ }^{C}$ Department of Pathology and Laboratory Medicine, Sheikh Khalifa Medical City, \\ Abu Dhabi, United Arab Emirates
}

\section{Key Words}

Primary gastric diffuse large B cell lymphoma · Computed tomography · Gastroscopy ·

Chemotherapy

\begin{abstract}
Though rare amongst stomach neoplasms, primary gastric diffuse large B cell lymphoma is one of the commonest extranodal non-Hodgkin lymphomas. If left untreated, it can have a devastating progression and life-threatening consequences. We present the case of a successfully treated large antral ulcer confirmed to be large B cell lymphoma as evidenced by radiologic, endoscopic and histopathologic findings. A brief discussion about the types of gastric lymphoma, their Helicobacter pylori relation and therapeutic modalities follows.
\end{abstract}

(C) 2014 S. Karger AG, Basel

\section{Introduction}

Although primary lymphoma of the gastrointestinal tract is rare, it remains one of the primary extranodal lymphoma sites. Primary gastrointestinal lymphoma involves any portion of the gastrointestinal tract from the mouth to the anal verge [1,2]. It can present in one or multiple sites with local or distant lymph node involvement [3]. Most gastrointestinal lymphomas are of the non-Hodgkin type and account for about $1-4 \%$ of gastrointestinal tract malignant tumors [4]. About $75 \%$ of gastrointestinal tract lymphomas are found in the

Abdelkarim Waness, MD, CPI, ABIM, FACP

Department of Medicine, Mafraq Hospital

PO Box 2951, Abu Dhabi (United Arab Emirates)

E-Mail awaness@mafraqhospital.ae 
Bismar et al.: A Case of Successful Remission of Extensive Primary Gastric Diffuse Large B Cell Lymphoma: Radiologic, Endoscopic and Pathologic Evidence

stomach, making it the most common site of extranodal involvement [5]. Only $3 \%$ of gastric neoplasms are primary lymphomas [6].

Gastric lymphoma does not have a typical presentation. The most common presenting symptoms, which might evolve within days to months, include epigastric pain (78\%), anorexia (47\%), weight loss (24\%), gastrointestinal bleeding (19\%), nausea and vomiting $(18 \%)$ and occasionally diarrhea (4\%). Gross upper gastrointestinal bleeding including hematemesis and melena are rare. About $4 \%$ of patients are asymptomatic [5].

Gastric lymphoma is usually diagnosed with upper endoscopy and biopsy. Surgical interventions are reserved for patients with complications. More than $90 \%$ of gastric lymphoma are divided into two histologic subtypes: the mucosa-associated lymphoid tissue (MALT) type (38-48\%) and the diffuse large B cell type (45-59\%) [7]. While the former responds well to Helicobacter pylori eradication, the latter is more aggressive, requiring extensive diagnostic workup and lengthy therapeutic intervention. The most common type of the remaining $10 \%$ of the gastric lymphomas include mantle cell, follicular and peripheral T cell forms $[5,7]$.

Primary diffuse large B cell lymphoma (DLBCL) is an aggressive type accounting for approximately $40 \%$ of all B cell malignancies [8]. Most DLBCLs have genetic abnormalities. There is no single cytogenetic change which is considered to be typical or diagnostic. DLBCLs demonstrate arrangement changes of both heavy and light chains of the immunoglobulin genes as well as somatic mutations of the variable region $[9,10]$. Confirmation of the DLBCL is usually done with histochemistry or flow cytometry. Tumor cells in DLBCLs manifest themselves mostly in the B cell antigens, including CD19, CD20, CD22, CD79a and CD45 [11].

The treatment options for gastrointestinal DLBCL include surgery, radiation, chemoimmunotherapy and eradication of $\mathrm{H}$. pylori infection. Combinations of these therapies may be utilized in certain cases. The majority of patients are treated with combination chemoimmunotherapy regimens similar to the one used for non-gastrointestinal DLBCL. Patients who present with perforation, obstruction or recurrent bleeding require surgical interventions [12-15].

\section{Case Presentation}

A 58-year-old diabetic man with dyspepsia was admitted because of weakness, dull abdominal pain and $10 \mathrm{~kg}$ weight loss within 3 months. He was on oral hypoglycemic agents and a proton pump inhibitor. His family history was unremarkable. The patient looked pale with the following vital signs: temperature $36.6^{\circ} \mathrm{C}$, heart rate $97 \mathrm{bpm}$, respiratory rate $16 / \mathrm{min}$, blood pressure $118 / 76 \mathrm{~mm} \mathrm{Hg}$ and oxygen saturation on room air $100 \%$. Epigastric tenderness was noted without rebound, organomegaly or palpable masses. Laboratory evaluation showed white blood cells $6.2 \times 10^{9} /$ l (range 4.5-10) with 60\% neutrophils and $20 \%$ lymphocytes, hemoglobin $102 \mathrm{~g} / \mathrm{l}$ (range 117-155), platelets $321 \times 10^{9} / \mathrm{l}$ (range 140-400), glucose $4 \mathrm{mmol} / \mathrm{l}$ (range 3.9-6.1), sodium $137 \mathrm{mmol} / \mathrm{l}$ (range 135-145), potassium $4.4 \mathrm{mmol} / \mathrm{l}$ (range 3.4-5.1), bicarbonate $23 \mathrm{mmol} / \mathrm{l}$ (range 22-29), serum creatinine $57 \mu \mathrm{mol} / \mathrm{l}$ (range 59-104), calcium $2.25 \mathrm{mmol} / \mathrm{l}$ (range 2.2-2.5) and serum lactate dehydrogenase $313 \mathrm{IU} / \mathrm{l}$ (range 135-225). The rest of his laboratory workup was unremarkable. The patient had an abdominal computed tomography (CT) scan showing diffuse asymmetric wall thickening of the pylorus and antrum of the stomach as well as of the first part of the duodenum (fig. 1). He subsequently underwent esophagogastroduodenoscopy (EGD) revealing a large deep friable gastric ulcer with a clean base occupying about $75 \%$ of the antrum (fig. 2). Multiple tissue biopsies were obtained and histopathology testing, with 
Bismar et al.: A Case of Successful Remission of Extensive Primary Gastric Diffuse Large B Cell Lymphoma: Radiologic, Endoscopic and Pathologic Evidence

immunohistochemistry, confirmed the diagnosis of DLBCL (fig. 3). The patient had a bone marrow aspiration with flow cytometry reported to be normal. CT scan of the chest and magnetic resonance imaging (MRI) of the brain were negative. A positron emission tomography scan confirmed a large gastric mass as well as several regional and mesenteric lymph nodes. His disease was staged as IV-A bulky high-grade primary gastric DLBCL (PG-DLBCL) with an International Prognostic Index score of 2/5. He had mild gastrointestinal bleeding complication after starting chemotherapy treatment requiring only blood transfusion. The patient received a total of eight cycles of rituximab, cyclophosphamide, doxorubicin, vincristine, etoposide and prednisolone (R-CHOEP). 14 months post treatment, the repeat lactate dehydrogenase level was $130 \mathrm{IU} / \mathrm{l}$, while a CT scan of the abdomen revealed resolution of the previous gastroduodenal thickening (fig. 4). Follow-up EGD showed complete healing of the antral ulcer (fig. 5). Histopathology confirmed the patient's total remission of his gastric lymphoma (fig. 6).

\section{Discussion}

One-third of non-Hodgkin lymphomas arise primarily from extranodal sites. Gastrointestinal tract involvement is the most common, with the stomach ahead of the small bowel [16]. Primary gastric lymphoma is an evolving pathology that remains rare (less than 5\%) compared to other stomach malignancies. The vast majority is made of either diffuse large B cell or MALT phenotypes [17]. The latter is known to be induced by H. pylori. Eradication of this microorganism is usually curative. PG-DLBCL, on the other hand, has a less defined relationship with $\mathrm{H}$. pylori. Some authors propose that a substantial portion of early-stage 'de novo' PG-DLBCLs are $H$. pylori-dependent and will respond well to $H$. pylori eradication [18]. PG-DLBCL can present as an aggressive fast-growing tumor. It can have a variety of symptoms including fatigue, anorexia, weight loss and abdominal pain. Tumor infiltration within the stomach wall can be complicated by major bleeding [19], gastric perforation [20] or even fistula formation with adjacent structures [21].

Diagnosing PG-DLBCL always involves multiple investigations. Besides clinical presentation and non-specific serum lymphocytosis, imaging modalities usually provide evidence of possible stomach involvement. Abdominal ultrasound, CT or MRI may show gastric wall thickening with or without intra-abdominal lymph nodes. Some authors advocate using endoscopic ultrasound for imaging and staging gastric lymphoma [22]. The staging process of PG-DLBCL is still being debated. It involves multiple clinical, serologic and radiologic parameters such as age, serum albumin and evidence of disease dissemination [23]. Developing improved diagnostic tools will shed further light on the complex nature of this disease.

PG-DLBCL is usually fatal if left untreated. The standard combination chemotherapy for large B cell lymphoma is the CHOP regimen: cyclophosphamide, doxorubicin, vincristine and prednisolone. As in our case, other agents such as etoposide and rituximab can be added. A recent study showed that adding rituximab to the CHOP combination did not impact the patients' cure rate [24]. Our patient did extremely well with eight cycles of R-CHOEP (R: rituximab, E: etoposide) and had an excellent response to the therapeutic management despite the unusually large size of his gastric ulcer. Follow-up CT, endoscopy and tissue biopsy showed evidence of complete remission of his gastric lymphoma. Besides the patient's good performance status, low serum lactate dehydrogenase levels are associated with longer disease-free survival [25]. 
Bismar et al.: A Case of Successful Remission of Extensive Primary Gastric Diffuse Large B Cell Lymphoma: Radiologic, Endoscopic and Pathologic Evidence

\section{Conclusions}

PG-DLBCL is an evolving pathology. Indeed, its H. pylori dependence and staging are still being developed. Modern diagnostic radiologic, endoscopic and histopathologic tools are shedding further light on the complexity of this disease. While CHOP is widely used to treat this condition, other therapeutic interventions are being explored. Ongoing and future research will likely bring forth new ways to understand and manage this unique form of lymphoma.

\section{Disclosure Statement}

The authors report no conflict of interest. There was no funding source.

\section{References}

1 Dawson IM, Cornes JS, Morson BC: Primary malignant lymphoid tumours of the intestinal tract. Report of 37 cases with a study of factors influencing prognosis. Br J Surg 1961;49:80-89.

-2 Lewin KJ, Ranchod M, Dorfman RF: Lymphomas of the gastrointestinal tract: a study of 117 cases presenting with gastrointestinal disease. Cancer 1978;42:693-707.

-3 Devaney K, Jaffe ES: The surgical pathology of gastrointestinal Hodgkin's disease. Am J Clin Pathol 1991;95: 794-801.

4 Loehr WJ, Mujahed Z, Zahn FD, Gray GF, Thorbjarnarson B: Primary lymphoma of the gastrointestinal tract: a review of 100 cases. Ann Surg 1969;170:232-238.

-5 Koch P, del Valle F, Berdel WE, Willich NA, Reers B, Hiddemann W, Grothaus-Pinke B, Reinartz G, Brockmann J, Temmesfeld A, Schmitz R, Rübe C, Probst A, Jaenke G, Bodenstein H, Junker A, Pott C, Schultze J, Heinecke A, Parwaresch R, Tiemann M; German Multicenter Study Group: Primary gastrointestinal non-Hodgkin's lymphoma: I. Anatomic and histologic distribution, clinical features, and survival data of 371 patients registered in the German Multicenter Study GIT NHL 01/92. J Clin Oncol 2001;19:3861-3873. Freeman C, Berg JW, Cutler SJ: Occurrence and prognosis of extranodal lymphomas. Cancer 1972;29:252260.

7 Papaxoinis G, Papageorgiou S, Rontogianni D, Kaloutsi V, Fountzilas G, Pavlidis N, Dimopoulos M, Tsatalas C, Xiros N, Economopoulos T: Primary gastrointestinal non-Hodgkin's lymphoma: a clinicopathologic study of 128 cases in Greece. A Hellenic Cooperative Oncology Group study (HeCOG). Leuk Lymphoma 2006;47: 2140-2146.

-8 Ottensmeier $\mathrm{CH}$, Stevenson FK: Isotype switch variants reveal clonally related subpopulations in diffuse large B-cell lymphoma. Blood 2000;96:2550-2556.

-9 Klein U, Goossens T, Fischer M, Kanzler H, Braeuninger A, Rajewsky K, Küppers R: Somatic hypermutation in normal and transformed human B cells. Immunol Rev 1998;162:261-280.

-10 Küppers R, Rajewsky K, Hansmann ML: Diffuse large cell lymphomas are derived from mature B cells carrying $\mathrm{V}$ region genes with a high load of somatic mutation and evidence of selection for antibody expression. Eur J Immunol 1997;27:1398-1405.

11 Stein H, Lennert K, Feller AC, Mason DY: Immunohistological analysis of human lymphoma: correlation of histological and immunological categories. Adv Cancer Res 1984;42:67-147.

-12 Salles G, Herbrecht R, Tilly H, Berger F, Brousse N, Gisselbrecht C, Coiffier B: Aggressive primary gastrointestinal lymphomas: review of 91 patients treated with the LNH-84 regimen. A study of the Groupe d'Etude des Lymphomes Agressifs. Am J Med 1991;90:77-84.

13 Gobbi PG, Dionigi P, Barbieri F, Corbella F, Bertoloni D, Grignani G, Jemos V, Pieresca C, Ascari E: The role of surgery in the multimodal treatment of primary gastric non-Hodgkin's lymphomas. A report of 76 cases and review of the literature. Cancer 1990;65:2528-2536.

14 Maor MH, Velasquez WS, Fuller LM, Silvermintz KB: Stomach conservation in stages IE and IIE gastric non-Hodgkin's lymphoma. J Clin Oncol 1990;8:266-271.

$\$ 15$ Cheung MC, Housri N, Ogilvie MP, Sola JE, Koniaris LG: Surgery does not adversely affect survival in primary gastrointestinal lymphoma. J Surg Oncol 2009;100:59-64.

16 Ghimire P, Wu GY, Zhu L: Primary gastrointestinal lymphoma. World J Gastroenterol 2011;17:697-707.

17 Yoshita H, Sugiyama T: Gastric malignant lymphoma. Nihon Rinsho 2012;70:1253-1262. 


\begin{tabular}{l|l}
\hline Case Rep Gastroenterol 2014;8:134-140 \\
\hline DOI: 10.1159/000362537 & $\begin{array}{l}\text { @ 2014 S. Karger AG, Basel } \\
\text { www.karger.com/crg }\end{array}$ \\
\hline
\end{tabular}

Bismar et al.: A Case of Successful Remission of Extensive Primary Gastric Diffuse Large B Cell Lymphoma: Radiologic, Endoscopic and Pathologic Evidence

18 Kuo SH, Yeh KH, Wu MS, Lin CW, Hsu PN, Wang HP, Chen LT, Cheng AL: Helicobacter pylori eradication therapy is effective in the treatment of early-stage H. pylori-positive gastric diffuse large B-cell lymphomas. Blood 2012;119:4838-4844; quiz 5057.

-19 Smolar M, Sutiak L, Mikolajcik A, Vojtko M, Plank L: Gastric lymphoma as a cause of massive bleeding in a patient with Castleman's disease. Rozhl Chir 2010;89:320-324.

-20 Shimada S, Gen T, Okamoto H: Malignant gastric lymphoma with spontaneous perforation. BMJ Case Rep 2013 DOI: 10.1136/bcr.05.2011.4251.

21 Jain V, Pauli E, Sharzehi K, Moyer M: Spontaneous gastrosplenic fistula secondary to diffuse large B-cell lymphoma. Gastrointest Endosc 2011;73:608-609.

-22 Vanis N, Mesihović R, Ibricević L, Dobrila-Dintinjana R: Predictive value of endoscopic ultrasound in diagnosis and staging of primary gastric lymphoma. Coll Antropol 2013;37(suppl 1):291-297.

23 Zhang J, Wang MY, Xu LC, Gu SY, Cao JN, Hu XC, Hong XN: Clinical analysis of primary gastric diffuse large B-cell lymphoma. Zhonghua Zhong Liu Za Zhi 2010;32:614-618.

24 Sohn BS, Kim SM, Yoon DH, Kim S, Lee DH, Kim JH, Lee SW, Huh J, Suh C: The comparison between CHOP and R-CHOP in primary gastric diffuse large B cell lymphoma. Ann Hematol 2012;91:1731-1739.

25 Medina-Franco H, Germes SS, Maldonado CL: Prognostic factors in primary gastric lymphoma. Ann Surg Oncol 2007;14:2239-2245.

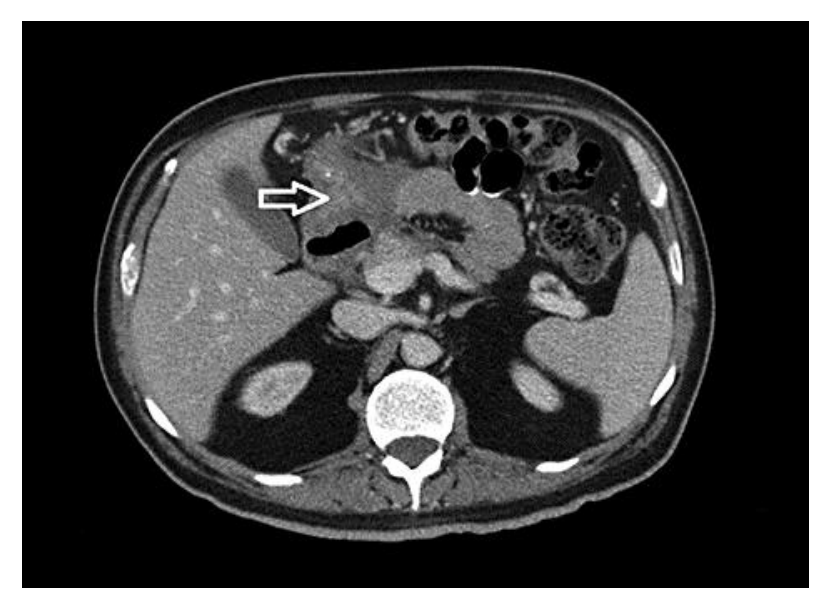

Fig. 1. CT scan of the abdomen showing diffuse asymmetric wall thickening of the pylorus and antrum (arrow).

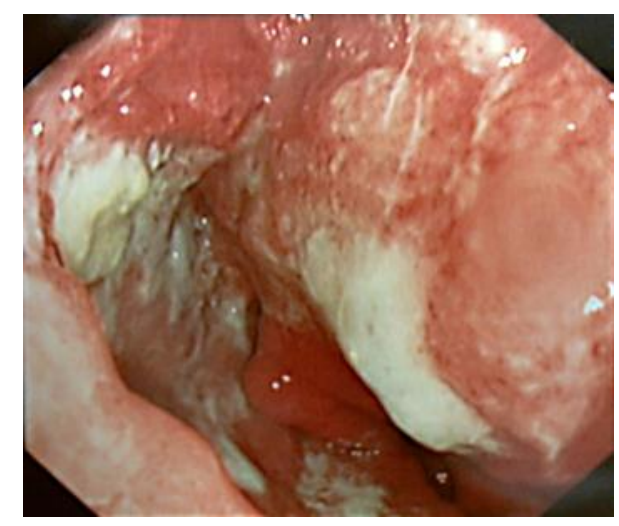

Fig. 2. Upper endoscopic view of a large friable ulcer occupying most of the gastric antrum. 
Bismar et al.: A Case of Successful Remission of Extensive Primary Gastric Diffuse Large B Cell Lymphoma: Radiologic, Endoscopic and Pathologic Evidence

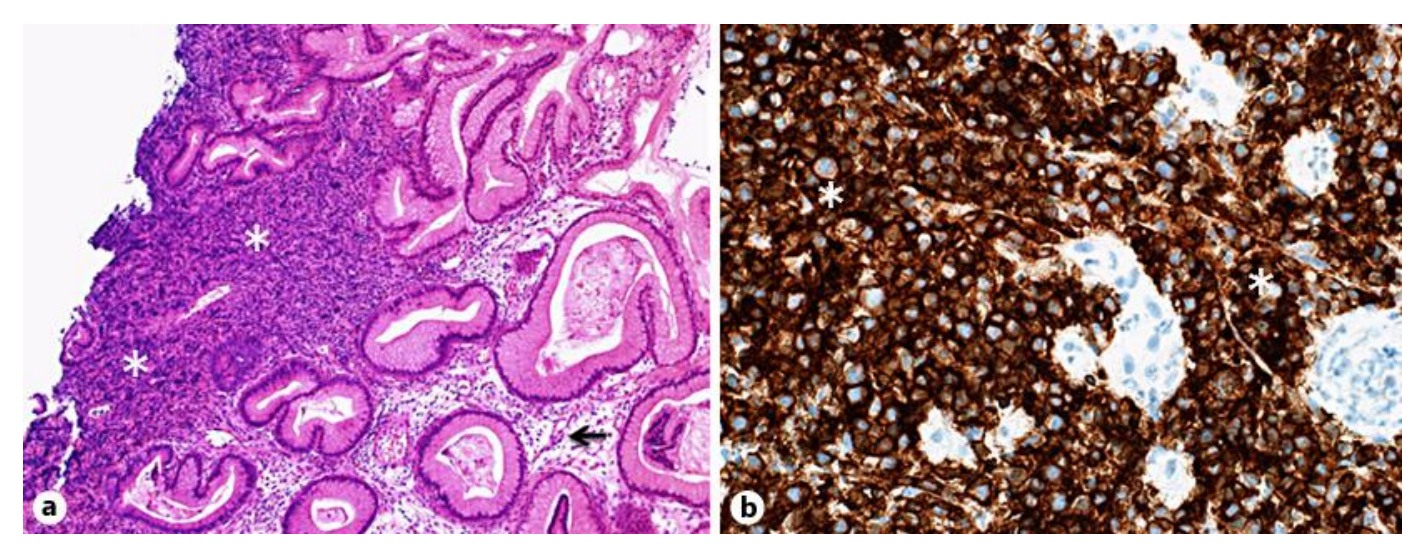

Fig. 3. a Low-magnification view of the stomach ulcer (H\&E stain, $\times 100)$. Invasion of the gastric lamina propria by sheets of medium to large atypical lymphoid cells (asterisks), compared to uninvolved areas (arrow) with sparse reactive inflammatory infiltrates. b High-magnification view of the atypical lymphoid infiltrates (CD20 IHC stain, $\times 200$ ). Diffuse cytoplasmic staining of the atypical lymphocytic infiltrates (asterisks) for anti-CD20 marker, indicating B lymphocyte cell origin.

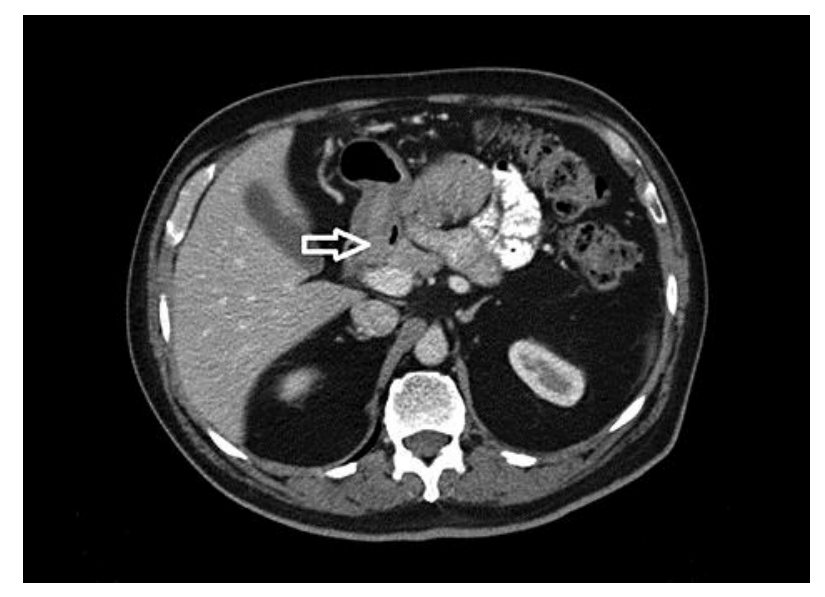

Fig. 4. Repeat CT scan of the abdomen post treatment. No visible thickening of the stomach wall (arrow). 
Case Reports in
Gastroenterology

\begin{tabular}{l|l}
\hline Case Rep Gastroenterol 2014;8:134-140 \\
\hline DOI: 10.1159/000362537 & $\begin{array}{l}\text { ○ 2014 S. Karger AG, Basel } \\
\text { www.karger.com/crg }\end{array}$ \\
\hline
\end{tabular}

Bismar et al:: A Case of Successful Remission of Extensive Primary Gastric Diffuse Large B Cell Lymphoma: Radiologic, Endoscopic and Pathologic Evidence

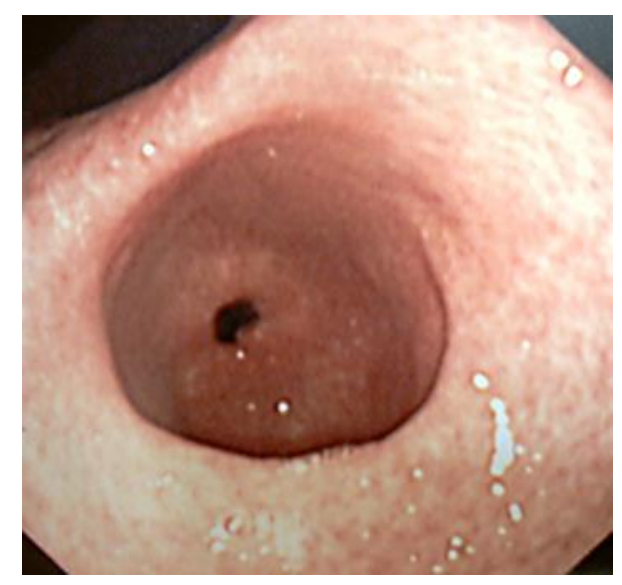

Fig. 5. Repeat endoscopic view post treatment. Normal appearance of the antrum and pylorus.

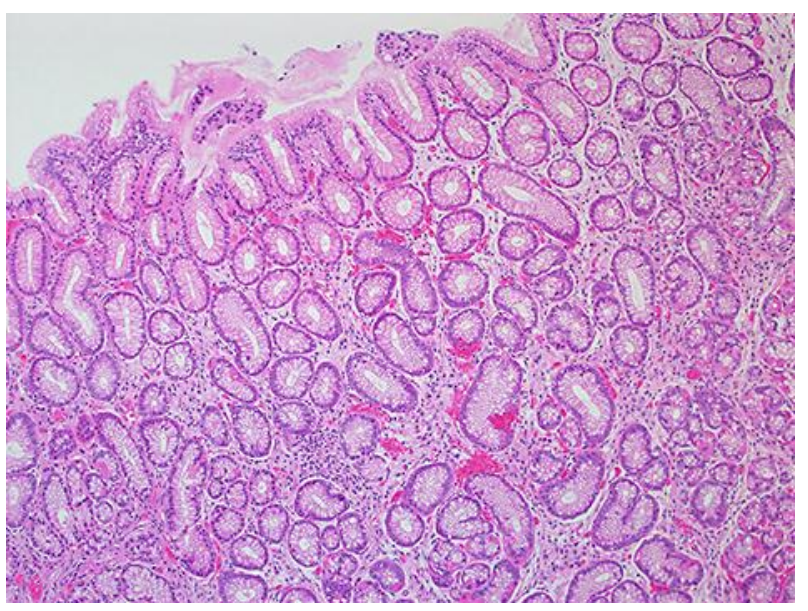

Fig. 6. Low-magnification view of the previous ulcer site post treatment (H\&E stain, $\times 100)$. No histopathologic evidence of residual tumor. 